\title{
Attracting Economics Majors
}

\author{
Ifeakandu Okoye, Florida A\&M University, USA
}

\begin{abstract}
A disturbing concern that has been expressed by academic economists is the low interest in economics as a major, as evidenced by the declining enrollment in most of the economics departments in American colleges and universities. Though some college and university economics departments are experiencing or had experienced a decline in their majors enrollment, others, in fact, have experienced an increase. The main purpose of this paper is to suggest innovative actions that economics departments experiencing declining enrollment can take in an effort to reverse the trend. The ideas presented in this paper can also benefit economics departments that have not experienced a decline in enrollment.
\end{abstract}

Keywords: undergraduate; economics majors; enrollment; pedagogy; repositioning

\section{BACKGROUND}

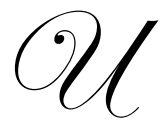

ndergraduate economics majors in U.S. colleges and universities experienced very significant declines in enrollment during the 1990s, which raised much concern among academic economists about the prospects of the discipline. The programs experienced a surge in enrollment between 1997 and 2004 (Siegfried, 2007). The bullish eight consecutive years of increased enrollment was punctuated by a decline in 2005, only to rise again in 2008 (Siegfried, 2010). Some of the earlier studies showed that the decline in enrollment began in 1992 and was more pronounced among private colleges and universities (Siegfried and Scott, 1994; and Salemi and Eubanks, 1996).

Reasons have been offered for the decline in enrollment in the economics major, but few ideas have been suggested on how to reverse the trend. The focus of this paper is to suggest some ideas that can effectively help to reverse the trend and maintain a stable enrollment in the future. Brasfield, et al (1996) found that while some economics departments were experiencing a decrease in enrollments, some, in fact, experienced an increase in enrollment, while others had no change. Nationally, however, they found a general decrease in enrollment, which they attributed to size effect of the large public universities whose enrollment fell. It has also been argued that the low enrollment in the economics major was due to the substitution effect between economics and business programs (Siegfried and Wilkinson, 1982; Brasfield, et al, 1996; Willis and Pieper, 1996, Salemi and Eubanks, 1996). Willis and Pieper (1996) confirmed findings by Siegfried and Wilkinson (1982) that the economics major is significantly affected by the availability of a business degree program, which, to students, is a close substitute to economics. They found that in those institutions with a selective or limited access business program, as the business degree becomes more or less popular, economics majors increase or decrease. Willis and Pieper also found a correlation between employment conditions in the financial services sector and majoring in economics. They argued that since the financial services sector is a major employer of economics graduates, a decline in employment demand in this sector - a proxy for the rate of return to investment in economics - will affect the number of students majoring in economics in the future. Their study also showed that if a school with a business degree has a business economics degree, enrollment in the economics major decreases very substantially because students view business economics as the best and closest alternative.

Salemi and Eubanks (1996) posit that students who were denied admission into business studies gravitate to economics as a major because to those students, economics is an alternative to business studies. They refer to this phenomenon as the discouraged-business-major (hereafter, DBM) hypothesis. Like Willis and Pieper, they find that as the popularity of a business degree rises and falls, so do majors in economics. Using data from the University of North Carolina in Chapel Hill, they tested the DBM hypothesis and found that although the proportion of the DBMs 
increased between 1983 and 1990 and decreased between 1990 and 1993, the DBMs account disproportionately for an increase in economics major. Margo and Siegfried (1996) examined the share of economics degrees relative to the total bachelor's degrees awarded in the post World War II, Korean and Vietnam wars eras and found that for the periods reviewed, the share of economics degrees awarded fluctuated around its long-run mean of about 2.2 percent.

Brasfield, et al. (1996) found that a decline in economics majors was greater in private than public institutions. They also found that the content, rather than the structure, of the introductory economics courses is a more significant factor in attracting economics majors. This supported findings by Bartlett (1995) that some potential economics majors failed to pursue economics because of the content of the principles courses. Furthermore, based on a survey of 200 economics departments' chairs, Brasfield, et al. found that economics departments in schools that do not have undergraduate business studies were more likely (95 percent) to lose majors than those in schools that have undergraduate business degree studies (63 percent). Given this, they concluded that in schools where economics is seen as an alternative for a business degree, availability of business degree programs account for some of the decline in economics degrees awarded. Like Willis and Pieper, this conclusion confirmed findings by Siegfried and Wilkinson (1982) that availability of a business degree program affects the number of economics majors (substitution effect hypothesis). They also argued that it appears that faculty diversity has a positive effect on the number of economics degrees awarded. For instance, they found that schools with increasing enrollment in economics tend to have a higher proportion of faculty who spoke English as a second language. Although the direction of the causality was not clear, the point, however, is that faculty diversity is an important variable that economics departments must consider if they hope to attract more economics majors.

\section{PREVIOUS SUGGESTIONS}

Where previous studies made an effort to explain the reasons for the low interest in economics as a major, few, however, provided suggestions that economics departments can adopt to reverse the decrease in enrollment. Becker (1997) and Margo and Siegfried (1996) suggested class size reduction for principles courses, which will allow instructors to try different pedagogical methods other than lecturing. They also suggested assigning popular instructors to teach principles courses. Bartlett (1995), on the other hand, argued that some potential economics majors fail to pursue economics because of the content of the principles courses and hence, suggested revising the content and methodology of economics principles courses so as to appeal to this group of potential students. Colander (2000) suggested that instructors use relevant stories, case studies and computer simulations in introductory courses to make them less boring to potential majors, while Becker (1997) was of the view that adopting group-work or cooperative learning will actively engage the students and hopefully interest them in majoring in economics. The implication of the later observations is that effective teaching techniques, other than the predominant lecturing method, can have some effect on some students' decision to major in economics (Jensen, E.J. and A.L. Owen, 2003; and Benzing, C. and P. Christ, 1997).

Another important suggestion provided was to de-emphasize the use of mathematical models (Bartlett, 1995 and Siegfried et al, 1991). As Siegfried, et al (1991) put it, "The important principles in macro and micro, however, can be learned without calculus, and how much calculus is actually used in undergraduate economics courses remains unknown. Calculus is not essential for all undergraduate economics majors, a great deal of the mathematics useful in economics is not covered in a first-year calculus course, and much of what is covered is never used in economics." This observation brings to focus the need for economics departments to acknowledge the fact that all economics majors are not graduate school bound and therefore, should review their curriculum with the view of producing a well-balanced curriculum that caters to the goals and needs of all their diverse majors. Essentially, rather than requiring general calculus and statistics for all economics majors, economics departments should allow students, who do not plan to pursue a graduate degree in economics, to substitute applied business calculus for general calculus and business and economic statistics for statistics.

While the above ideas by previous studies are good, some did not go far enough to the core of the problem. For instance, given that colleges and universities are not immune from budgetary cuts during periods of economic recession, the strategy of reducing class size in order to attract economics majors may not be cost effective in most institutions, especially in large public institutions. Therefore, what can economics departments do to reverse the declining enrollment in economics majors? 


\section{SUGGESTIONS FOR REVERSING MAJORS DECLINE}

As indicated earlier, the primary objective of this paper is to suggest innovative actions that economics departments can take to promote the economics major to potential students. Below are some ideas that the author believes will enable economics departments to attract more majors if properly implemented.

1. With due consideration to the ideas by previous studies mentioned above, the author believes that a more feasible approach economics departments can adopt to improve their enrollment in majors is to reposition the economics degree program. The strategy of repositioning involves redoing a product's position to respond to the changing marketplace or needs of the target market (Solomon, et al., 2009). For instance, academic programs, such as economics, accounting, and agriculture, to name a few, are services produced by institutions and, like traditional firms' products/services that are often repositioned when the product's/services' market share falls, an academic program can also be repositioned if it is experiencing significant decline in enrollment as is the case with economics. Repositioning economics degree programs will require strengthening the program's core competency and channeling it to address and find answers to real economic issues facing households, firms, and governments. Now, more than ever, economics departments should focus on producing graduates who can apply theoretical knowledge into practical solutions that work. The society needs such economists and we cannot ignore that need any longer.

2. To effectively reposition the economics major and make it more appealing to the targeted students' ideals, economics departments must try to understand the needs and concerns of the students. It seems plausible to assume that a major concern of most economics majors is the mathematics requirements of the economics degree program. Mathematics, no doubt, is good and necessary, but mathematics should be seen as a tool, not an end. If we cannot transform the theoretical and mathematical knowledge into useful practical applications, we not only fail ourselves, but we also fail the students and the society as a whole. As Siegfried, et al., (1991) put it, "a great deal of the mathematics useful in economics is not covered in a firstyear calculus course and much of what is covered is never used in economics." Given this observation, the author strongly suggests that those students who do not intend to pursue a graduate economics degree program be allowed to substitute applied business calculus for general calculus. The mathematics (calculus, mathematical statistics, etc) requirements would be restricted only to those students who have great aptitude for mathematics and who plan to pursue a graduate economics degree program. This way, economics departments will be effectively catering to distinct market segments.

3. Economics departments, therefore, should seriously consider adopting an applied approach, rather than an abstract theoretical approach, for some or all tracks of their undergraduate degree program. The proposed applied approach demands that instructors relate the materials taught in the classrooms to real world issues more than to theoretical abstractions. To achieve these objectives, economics departments will have to change their curriculum to reflect applied economics. For instance, the courses will include, but not be limited to, applied microeconomic analysis, applied time series analysis, business calculus, economic development, applied business forecasting, cost-benefit analysis, economic and business statistics, managerial economics, and applied econometrics, to name just a few. These and other courses should be loaded with hands-on real world case studies, projects and application problem sets. People live in the real world, and if economists can endeavor to find real answers to economic and public policy issues, they will regain the luster they once commanded.

4. Economics departments should consider partnering with organizations, such as banks, insurance and brokerage firms, Ford, Wal-Mart, Coca-Cola, Proctor \& Gamble, and non-profits, such as hospitals and state and local governments, to provide opportunities for their students to apply what they have learned in class and gain valuable experiences before graduation. This partnership will help economics departments strengthen their programs as they learn what these organizations want the students - the organizations' potential employees - to know in order to be a good fit for their organizations. This, ultimately, will help prepare the students well for the labor market upon graduation. Assuming this investment in the partnership is successful, it becomes an asset that the departments can proudly include in their brochures with the expectations that it will appeal to more potential students and hence, attract them to major in economics.

5. Equally important is the establishment of good relationships with local TV stations. This will provide an avenue for the economics departments to showcase their significant projects. They should also let the news media know that the economics department will welcome invitations to discuss any current topical 
economic, social and public policy issues facing their local government, state, or the country. Furthermore, they may also collaborate with the state government for their advanced students (juniors and seniors) to work with the legislators as junior economic policy aides. The students must be supervised by a faculty with strength in state and local government, public finance, public policy and project evaluation, and applied micro and macro analysis. At the end of such cooperative (internship) assignments, the students should submit a 20-page report on the student's key assignments to the department and present the same to the faculty and students.

6. Economics departments must, as a necessity, have a teaching computing lab with sufficient computers for economics majors only. The computer lab should be equipped with common software, such a SAS, SPSS, STATA, RATS, EViews, SHAZAM, etc., and with complete user manuals. The computer lab will require an attendant who is knowledgeable in systems network/administration to maintain the lab. This position can be easily filled with computer science majors of junior or senior standing on work-study and thus substantially reduce the lab operating costs. The benefit of the teaching computing lab is that it will provide the majors a great opportunity for hands-on applications, culminating in proficiency in data analysis and mastery of the various software.

7. Economics departments should also encourage their majors to form an active economics student association, and further encourage them to invite corporate executives, successful entrepreneurs, and government officials to discuss economic, business, and public policy matters. If the departments have professional development courses, attendance would be mandatory for students registered in professional development courses. As a support to the students, instructors who do not have classes during a visiting guest's presentation should attend the presentation.

8. More importantly, it will be wise to let the potential students know a few notable economics graduates and other economists or economics majors and their achievements. The students should know that these individuals achieved their ambitions because of their knowledge of economics, hard work and enthusiasm, and if they apply themselves, they too can become great in the future. The list, no doubt, is long, but for the purpose of attracting economics majors, the list should contain those individuals the potential students can easily recognize, such as Sam Walton of Wal-Mart; Fred Smith of FedEx; Sandra Day O'Connor of the US Supreme Court; Mick Jagger of the Rolling Stones; Tiger Woods, the greatest golfer; Steve Ballmer, CEO of Microsoft; Ronald Reagan, former US President; Lenny Wilkens, NBA Coach; John Maynard Keynes whose ideas helped save the world from the Great Depression; Adam Smith, considered by many as the founder of modern economics; and David Ricardo, for his compelling theory of comparative advantage, to name just a few.

\section{SUMMARY}

Economics is, for all practical purposes, the "mother of all business disciplines", and the fact that it is losing ground to its "offsprings", as evidenced by the decline in majors enrollment, should certainly raise some concerns for academic economists. Economics departments, especially those experiencing falling majors, should seriously consider adopting the innovative ideas discussed above if they hope to reverse the trend. The departments cannot rely too long on such short-term solutions as grade inflation, and there may not be many popular instructors available to be assigned to the principles courses to motivate the undecided students to major in economics. Smaller classes sound appealing as a good strategy to forestall the falling enrollment; however, financial constraints may make it difficult to achieve. Also, economics departments must reconsider modifying their mathematics requirements for all economics majors. Unless a student plans on pursuing graduate degree program in economics, they should be allowed to substitute applied business calculus for general calculus and economics and business statistics for general statistics. In short, they should offer multiple undergraduate degree options to accommodate the goals and needs of all their diverse majors.

It is understandable that there may be other ideas that may help forestall the decline in enrollment; however, for economics departments seeking to increase the number of economics majors, the eight ideas suggested above may just be all they need to reverse the trend. In as much as the ideas are not costless, substantial costs would not be required to implement the eight ideas suggested above. Some economics departments may already have the faculty that can effectively teach the applied courses. If they don't and they expect to hire more faculty as funds become available, they should seize the opportunity to hire individuals with the needed background for the take-off. 
Also, rather than relying on, or waiting for their institutions to provide a teaching computing lab, the economics departments can solicit help from corporations to establish the lab. Now, more than ever, the society needs policyoriented economists who can apply theoretical knowledge into practical solutions that work. Economics departments should focus on producing such economists by giving serious consideration to adopting the applied approach suggested in this paper.

\section{AUTHOR INFORMATION}

Dr. Ifeakandu N. Okoye is an assistant professor in the department of economics at Florida A\&M University, in Tallahassee, Florida. He teaches principles of economics and upper level courses in labor, public finance, health, mathematical economics, and economics of managerial finance. Dr. Okoye received his $\mathrm{PhD}$ in economics from Wayne State University. The author thanks David Colander and other conference participants at Robert Morris University for valuable comments and encouragement. E-mail: ifeakandu.okoye@ famu.edu.

\section{REFERENCES}

1. Bartlett, R.L. 1995. Attracting "Otherwise Bright Students" to Economics 101. American Economic Review, 85(2), pp 362-366.

2. Becker, W.E. 1997. Teaching Economics To Undergraduates. Journal of Economic Literature, vol. XXXV (Sept 1997), pp1347-1373.

3. Benzing, C. and Paul Christ. 1997. A Survey of Teaching Methods Among Economics Faculty. Journal of Economic Education, 28(2), pp 182-189.

4. Brasfield, D., D. Harrison, J. McCoy and M. Milkman. 1996. Why Have Some Schools Not Experienced A Decrease in The Percentage of Students Majoring In Economics? Journal of Economic Education, 27(4), pp 362-370.

5. Colander, D. 2000. Telling Better Stories in Introductory Macro. American Economic Review, 90(2), pp7620.

6. Jensen, E.J. and Ann L. Owen. 2003. Appealing To Good Students in Introductory Economics. Journal of Economic Education, 34(4), pp299-325.

7. Margo, R.A. and John J. Siegfried. 1996. Long-Run Trend in Economics Bachelor's Degrees. Journal of Economic Education, Fall 1996, 27(4), pp326-336.

8. Willis, R.A. and P.J. Pieper. 1996. The Economics Major: A Cross-Sectional View. Journal of Economic Education, Fall 1996, 27(4), pp 337-349.

9. Salemi, M.K. and C. Eubanks. 1996. Accounting for The Rise and Fall in The Number of Economics Majors With The Discouraged-Business-Major Hypothesis. Journal of Economic Education, Fall 1996, 27(4), pp350-361.

10. Siegfried, J.J and J.T. Wilkinson. 1982. The Economics Curriculum in 1980. American Economic Review, 72(2), pp125-138.

11. Siegfried, J.J. ET AL. 1991. "The Status and Prospects of The Economics Major.” Journal of Economic Education, Summer 1991, 22(3), pp197-224.

12. Siegfried, J.J. and C.E. Scott. 1994. Recent Trends in Undergraduate Economics Degree. Journal of Economic Education, 25(3), pp281-286.

13. Siegfried, J.J. 2007. Trends in Undergraduate Economics Degrees, 1991-2006. Journal of Economic Education, Summer 2007, 38(3), pp 360-361.

14. Siegfried, J.J. 2010. Trends in Undergraduate Economics Degrees, 1991-2009. Journal of Economic Education, 41(3), pp 326-330.

15. Solomon, M.R., G.W. Marshall, and E.W. Stuart. Marketing Real People Real Choices. Saddle River, N.J: Pearson Publishers, 2009. 
NOTES 